\title{
PELATIHAN PENCATATAN DAN PELAPORAN KEUANGAN DESA DI DESA SAMBANGAN KECAMATAN BATI-BATI
}

\author{
Yuli Fitriyani*, Radna Nurmalina, Rina Febriana \\ Program Studi Akuntansi, Politeknik Negeri Tanah Laut \\ Jl. A. Yani, Km 6, Ds. Panggung, kec. Pelaihari, kab Tanah Laut, Kalimantan Selatan \\ *Korespondensi penulis, email: yulihazami@gmail.com
}

\begin{abstract}
Abstrak: Desa Sambangan Kecamatan Bati-Bati merupakan salah satu tempat kegiatan Desa Binaan Politeknik Negeri Tanah Laut. Pengembangan desa binaan ini merupakan program yang berorientasi kepada penyelesaian masalah di lingkungan masyarakat. Program ini dimaksudkan untuk membantu menyelesaikan masalah yang dihadapi oleh masyarakat, mengurangi beban kehidupan masyarakat, menuntut masyarakat kearah kehidupan yang lebih sejahtera, mewujudkan masyarakat yang dinamis, membantu dan meningkatkan kondisi sosial ekonomi warga dan mempermudah akses warga terhadap informasi dan ilmu pengetahuan. Pengelolaan keuangan Desa tidak hanya menyangkut perlunya peraturan pendukungnya dan sarana-prasarana, namun yang paling penting adalah dimilikinya SDM yang memiliki kompetensi dan komitmen yang dapat diandalkan. Kita sadari bahwa aparat Desa yang ada saat ini sebagian besar memiliki tingkat pendidikan yang relatif rendah. Untuk itu maka pengelolaan Keuangan Desa ini perlu dibuat agar dapat digunakan sebagai langkah untuk mempermudah pengelolaan akuntansi dari keuangan Desa sehingga nantinya dapat dipertanggungjawabkan secara benar. Pelatihan ini berusaha untuk memberikan pemahaman terhadap pengelolaan keuangan Desa dengan cara yang mudah sehingga tidak akan membuat ketakutan bagi siapapun untuk dapat mempertanggungjawabkan pengelolaan keuangan Desa dengan baik. Pendekatan dari pelatihan pencatatan ini adalah memberikan pemahaman terhadap alur pikir bagaimana pemerintah desa dapat menyusun laporan keuangannya. Dalam pelaksanaannya pengelolaan keuangan desa ini dapat dikembangkan dalam bentuk suatu aplikasi, namun di sisi lain mengingat keterbatasan dari pemerintah desa yang bersangkutan maka pengelolaannya dapat dilakukan dengan cara manual seperti yang dicontohkan dengan menggunakan berbagai formulir pada pelatihan pencatatan laporan keuangan desa ini.
\end{abstract}

Kata Kunci: Pencatatan, Pengelolaan Keuangan Desa, Desa Sambangan Bati-Bati.

\section{PENDAHULUAN}

\section{A. Definisi Pengelolaan Keuangan Desa.}

Dengan diberlakukannya Undang-undang

Nomor 6 Tahun 2014 tentang Desa, maka yang menjadi perhatian kita bersama adalah bagaimana selanjutnya pemerintahan desa Mengelola keuangan dan mempertanggung jawabkannya.

Menurut pasal 71 ayat (1) UU Nomor 6

Tahun 2014 dinyatakan bahwa Keuangan

Desa adalah hak dan kewajiban Desa yang dapat dinilai dengan uang serta segala sesuatu berupa uang dan barang yang

berhubungan dengan pelaksanaan hak dan

kewajiban Desa. Selanjutnya pada ayat (2) nyadinyatakan bahwa adanya hak dan kewajiban akan menimbulkan pendapatan, belanja, pembiayaan, dan pengelolaan Keuangan Desa. Dengan diberlakukannya Peraturan Pemerintah Nomor 43 Tahun 2014 tentang Peraturan Pelaksanaan Undang-undang Nomor 6 Tahun 2014 
tentang Desa, maka kita coba jabarkan apa yang sebelumnya diatur pada UU Nomor 6 Tahun 2014, di antaranya :

Pasal 93 ayat (1) menyatakan bahwa pengelolaan keuangan Desa meliputi : perencanaan, pelaksanaan, penatausahaan, pelaporan, dan pertanggungjawaban. Berdasarkan pasal 105 dinyatakan ketentuan mengenai pengelolaan keuangan Desa akan diatur dalam Peraturan Menteri ( maksudnya Menteri Dalam Negeri). Selanjutnya pasal 94 menyatakan bahwa pengelolaan keuangan Desa dilaksanakan dalam masa 1 (satu) tahun anggaran terhitung mulai tanggal 1 Januari sampai dengan 31 Desember. Pasal 103 menyatakan bahwa Kepala Desa menyampaikan laporan realisasi pelaksanaan APBDesa kepada Bupati/Walikota setiap semester tahun berjalan. Laporan semester pertama disampaikan paling lambat pada akhir bulan Juli tahun berjalan. Sedangkan laporan semester kedua disampaikan paling lambat pada akhir Januari tahun berikutnya.

\section{B. Anggaran Pendapatan dan Belanja Desa (APBDesa)}

Menurut Pedoman Asistensi Akuntansi Keuangan Desa (2015) APBDesa pada dasarnya adalah rencana keuangan tahunan Pemerintahan Desa. APBDesa terdiri atas :

\section{Pendapatan Desa}

Meliputi semua penerimaan uang melalui rekening desa yang merupakan hak desa dalam 1 (satu) tahun anggaran yang tidak perlu dibayar kembali oleh desa. Pendapatan desa diklasifikasikan menurut kelompok dan jenis.

\section{Belanja Desa}

Meliputi semua pengeluaran dari rekening desa yang merupakan kewajiban Desa dalam 1 (satu) tahun anggaran yang tidak akan diperoleh pembayarannya kembali oleh desa. Belanja desa dipergunakan dalam rangka mendanai penyelenggaraan kewenangan desa dan diklasifikasikan menurut kelompok, kegiatan, dan jenis.

\section{Pembiayaan Desa}

Meliputi semua penerimaan yang perlu dibayar kembali dan/atau pengeluaran yang akan diterima kembali, baik pada tahun anggaran yang bersangkutan maupun pada tahun-tahun anggaran berikutnya. Pembiayaan desa terdiri atas Penerimaan Pembiayaan dan Pengeluaran Pembiayaan yang diklasifikasikan menurut kelompok dan jenis.

\section{Pengelolaan Keuangan Desa}


Sebagaimana telah dinyatakan sebelumnya, pengelolaan keuangan Desa meliputi: perencanaan, pelaksanaan, penatausahaan, pelaporan, dan pertanggungjawaban yang dapat dijelaskan sebagai berikut :

\section{Perencanaan}

a. Rancangan Peraturan Desa tentang APBDesa dibuat, disampaikan oleh Kepala Desa, dan dibahas dengan Badan Permusyawaratan Desa untuk disepakati bersama paling lambat bulan Oktober tahun berjalan.

b. Rancangan Peraturan Desa tentang APBDesa yang telah disepakati disampaikan oleh Kepala Desa kepada Bupati/Walikota melalui camat atau sebutan lain paling lambat 3 (tiga) hari sejak disepakati untuk dievaluasi.

c. Bupati/Walikota melakukan evaluasi paling lama 20 (dua puluh) hari kerja sejak diterimanya Rancangan Peraturan Desa tentang APBDesa.Dalam hal Bupati/Walikota tidak melakukan evaluasi dalam batas waktu tersebut, maka Peraturan Desa berlaku dengan sendirinya.

d. Dalam hal ada koreksi yang disampaikan atau penyesuaian yang harus dilakukan dari hasil evaluasi tersebut, maka Kepala Desa harus melakukan penyempurnaan paling lama 7 (tujuh) hari kerja sejak diterimanya hasil evaluasi.

e. Apabila hasil evaluasi tidak ditindaklanjuti oleh Kepala Desa dan Kepala Desa tetap menetapkan Rancangan Peraturan Kepala Desa tentang APBDesa menjadi Peraturan Desa, Bupati/Walikota membatalkan Peraturan Desa dengan Keputusan Bupati/Walikota. Dengan dilakukannya pembatalan Peraturan Desa tersebut sekaligus menyatakan berlakunya pagu APBDesa tahun anggaran sebelumnya. Dalam hal terjadi pembatalan, Kepala Desa hanya dapat melakukan pengeluaran terhadap operasional penyelenggaraan Pemerintah Desa.

f. Kepala Desa memberhentikan pelaksanaan Peraturan Desa paling lama 7 (tujuh) hari kerja setelah pembatalan dan selanjutnya bersama BPD mencabut peraturan desa dimaksud.

g. Dalam hal Bupati/Walikota mendelegasikan evaluasi Rancangan Peraturan Desa tentang APBDesa kepada Camat atau sebutan lain, maka langkah yang dilakukan adalah :

1). Camat menetapkan hasil evaluasi Rancangan APBDesa paling lama 
20 (dua puluh) hari kerja sejak diterimanya Rancangan Peraturan Desa tentang APBDesa.

2). Dalam hal Camat tidak memberikan hasil evaluasi dalam batas waktu yang ditetapkan, Peraturan Desa tersebut berlaku dengan sendirinya.

3). Dalam hal ada koreksi yang disampaikan atau penyesuaian yang harus dilakukan dari hasil evaluasi tersebut, Kepala Desa melakukan penyempurnaan paling lama 7 (tujuh) hari kerja terhitung sejak diterimanya hasil evaluasi.

4).Apabila hasil evaluasi tidak ditindaklanjuti oleh Kepala Desa dan Kepala Desa tetap menetapkan Rancangan Peraturan Kepala Desa tentang APBDesa menjadi Peraturan Desa, Camat menyampaikan usulan pembatalan Peraturan Desa kepada Bupati/Walikota.

\section{Pelaksanaan}

a. Semua penerimaan dan pengeluaran desa dalam rangka pelaksanaan kewenangan desa dilaksanakan melalui rekening kas desa.

b. Semua penerimaan dan pengeluaran desa harus didukung oleh bukti yang lengkap dan sah. c. Pemerintah desa dilarang melakukan pungutan sebagai penerimaan desa selain yang ditetapkan dalam peraturan desa.

d. Bendahara dapat menyimpan uang dalam Kas Desa pada jumlah tertentu dalam rangka memenuhi kebutuhan operasional pemerintah desa.

e. Pengeluaran desa yang mengakibatkan beban APBDesa tidak dapat dilakukan sebelum rancangan peraturan desa tentang APBDesa ditetapkan menjadi peraturan desa.

f. Pengeluaran desa untuk belanja pegawai yang bersifat mengikat dan operasional perkantoran yang ditetapkan dalam peraturan kepala desa tetap dapat dikeluarkan walaupun rancangan peraturan desa tentang

APBDesa belum ditetapkan.

g. Pelaksana Kegiatan mengajukan pendanaan untuk melaksanakan kegiatan harus disertai dengan dokumen diantaranya Rencana Anggara Biaya (RAB). Sebelum digunakan, RAB tersebut diverifikasi oleh Sekretaris Desa dan disahkan oleh Kepala Desa.

h. Pelaksana Kegiatan bertanggungjawab terhadap tindakan yang menyebabkan pengeluaran atas beban anggaran belanja kegiatan dengan mempergunakan Buku 
Pembantu Kas Kegiatan sebagai pertanggungjawaban pelaksanaan kegiatan desa.

\section{Penatausahaan}

Bendahara desa wajib :

a. Melakukan pencatatan setiap penerimaan dan pengeluaran serta melakukan tutup buku setiap akhir bulan secara tertib. Penatausahaan penerimaan dan pengeluaran dilakukan menggunakan : Buku Kas Umum, Buku Kas Pembantu Pajak, dan Buku Bank.

b. Mempertanggungjawabkan uang melalui laporan pertanggungjawaban.

\section{Pelaporan}

Kepala desa menyampaikan laporan realisasi pelaksanaan APBDesa kepada Bupati/Walikota yang meliputi :

a. Laporan semester pertama, berupa Laporan Realisasi Pelaksanaan APBDesa.Semester Pertama.

b. Laporan semester akhir tahun, berupa Laporan Realisasi Pelaksanaan APBDesa Semester Akhir.

\section{Pertanggungjawaban}

Kepala desa menyampaikan kepada Bupati /Walikota setiap akhir tahun anggaran laporan yang meliputi :

a. Laporan Pertanggungjawaban Realisasi Pelaksanaan APBDesa Tahun Anggaran berkenaan.
1) Merupakan bagian tidak terpisahkan dari laporan penyelenggaraan Pemerintahan Desa.

2) Diinformasikan kepada masyarakat secara tertulis dan dengan media informasi yang mudah diakses oleh masyarakat.

3) Disampaikan kepada Bupati/Walikota melalui camat atau sebutan lain.

b. Laporan Kekayaan Milik Desa per 31

Desember Tahun Anggaran

berkenaan

c. Laporan Program Pemerintah dan Pemerintah Daerah yang masuk ke desa.

\section{Pembinaan dan Pengawasan}

a. Pemerintah Provinsi wajib membina dan mengawasi pemberian dan penyaluran Dana Desa, Alokasi Dana Desa, dan Bagi Hasil Pajak dan Retribusi Daerah dari Kabupaten/Kota kepada Desa.

b. Pemerintah Kabupaten/Kota wajib membina dan mengawasi pelaksanaan pengelolaan keuangan desa.

\section{METODE PELAKSANAAN}

Kegiatan pengabdian kepada masyarakat dilaksanakan dengan cara melakukan pelatihan dan Pencatatan langsung atau workshop di Desa Sambangan Kecamatan Bati-Bati. Materi disesuaikan dengan kemampuan peserta pelatihan. Pelaksanaan kegiatan dibantu oleh mahasiswa, sehingga 
setiap ada peserta (masyarakat desa) yang kurang memahami materi maka akan dibimbing oleh mahasiswa sehingga tidak menghambat materi yang disampaikan oleh tutor.

\section{HASIL KEGIATAN}

Kegiatan pengabdian kepada Masyarakat ini melakukan beberapa tahapan yaitu acara di awali dengan melakukan pembukaan oleh Direktur Politeknik Negeri Tanah Laut dan juga sambutan ketua tokoh masyarakat/ yang mewakili.. Setelah itu diberikan sosialisasi mengenai Pelatihan Pencatatan dan Pelaporan Keuangan Desa kepada Masyarakat Desa Sambangan.

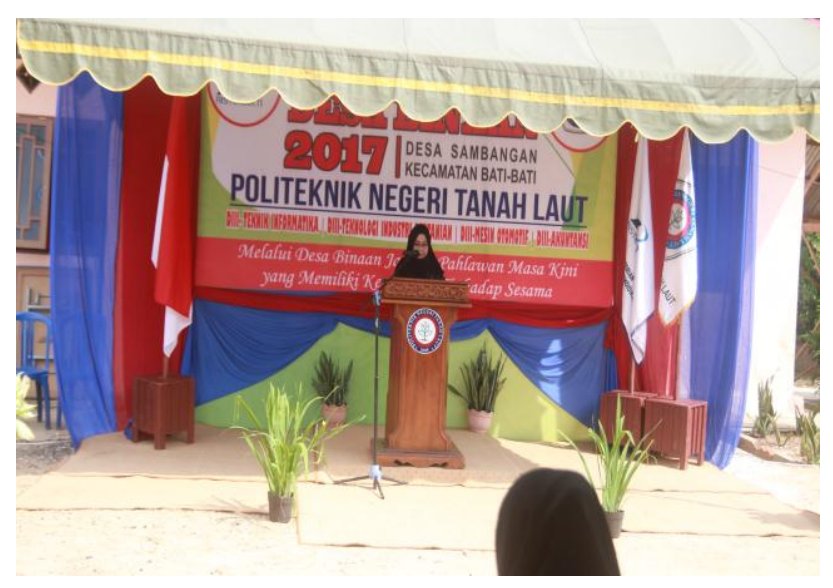

Gambar 1: Pembukaan yang disampaikan oleh Ibu Direktur Politeknik Negeri Tanah Laut

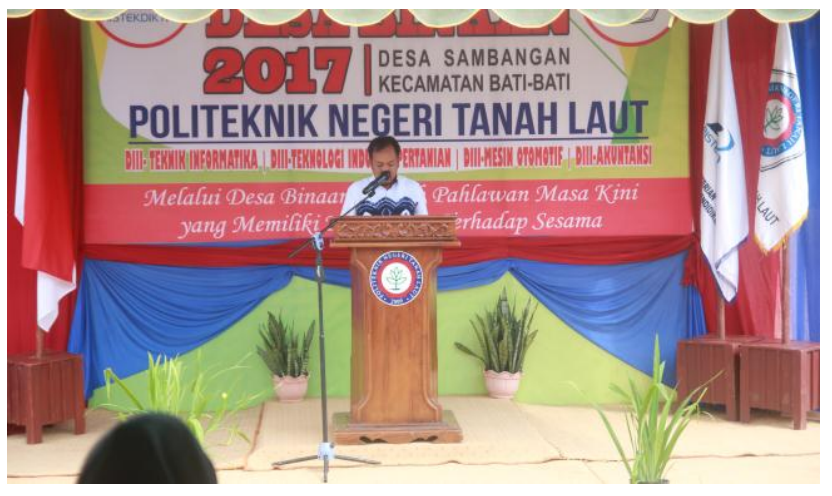

Gambar 2: Sambutan dari Tokoh Masyarakat Desa

Sambangan

Pelatihan dilaksanakan di Desa Sambangan Kecamatan Bati-Bati. Program ini dimaksudkan untuk membantu menyelesaikan masalah yang dihadapi oleh masyarakat, mengurangi beban kehidupan masyarakat, menuntut masyarakat kearah kehidupan yang lebih sejahtera, mewujudkan masyarakat yang dinamis, membantu dan meningkatkan kondisi sosial ekonomi warga dan mempermudah akses warga terhadap informasi dan ilmu pengetahuan.

Hasil dari pelaksanaan kegiatan pengabdian kepada masyarakat Desa Binaan "Pelatihan Pencatatan dan Pelaporan Keuangan Desa" berupa pelatihan pembelajaran ini adalah peserta menjadi lebih familiar dengan Pelaporan keuangan Desa secara manual. 


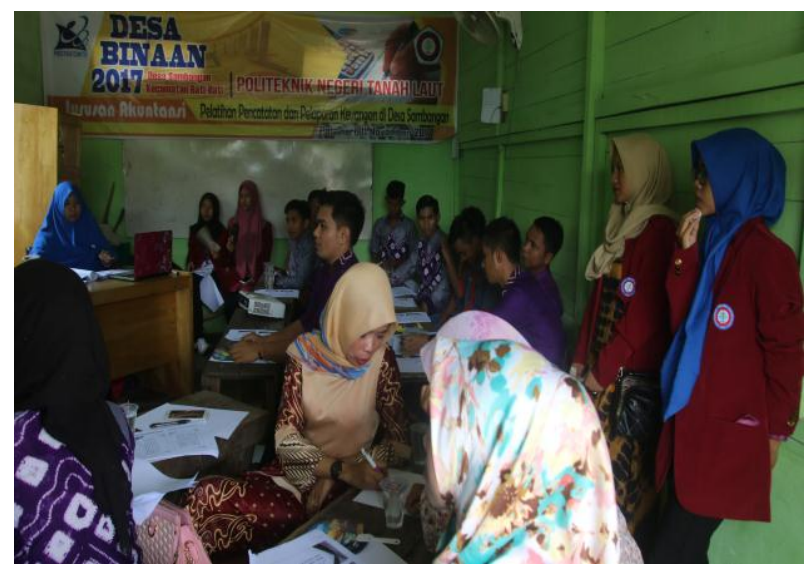

Gambar 3: Simulasi Pelatihan Pencatatan dan Pelaporan Keuangan Desa

\section{KESIMPULAN}

Kegiatan pengabdian kepada masyarakat Desa Binaan "Pelatihan Pencatatan dan Pelaporan Keuangan Desa" berupa pelatihan secara manual yang dilaksanakan oleh Program Studi Akuntansi di Politeknik Negeri Tanah Laut telah sukses dilaksanakan. Pelatihan ini membantu peserta meningkatkan pengetahuan dan kemampuannya dalam membuat Pencatatan dan Pelaporan Keuangan Desa.

Berdasarkan apresiasi dari para peserta pelatihan yang berjumlah 15 orang, kegiatan ini diharapkan berlangsung secara kontinyu dengan materi yang juga saling berhubungan sehingga dapat terus membantu meningkatkan sumberdaya manusia khususnya para pengguna laporan keuangan di Desa Sambangan Kecamatan Bati-Bati.

\section{DAFTAR PUSTAKA}

IAI- KASP. 2015. Pedoman Asistensi Akuntansi Keuangan Desa. Ikatan Akuntansi Indonesia.

https:// www.google.co.id / Akuntansi Desa Keuangan Desa dan Pengelola Keuangan Desa /

www.keuangandesa.info > Keuangan Desa > Pelaporan > Standar

www.bpkp.go.id/sakd/konten/2448/LeafletSimda-Desa.bpkp 